\title{
Smart Farmer Application in Monitoring and Learning of Android-based Rice Cultivation
}

\author{
Rian Farta Wijaya, Andysah Putera Utama Siahaan, Rahmad Budi Utomo, Debi Yandra Niska \\ Faculty of Science and Technology, Universitas Pembangunan Panca Budi, Medan, Indonesia
}

\begin{abstract}
Farmers are jobs that are done by planting crops and then harvesting crops for sale or consumption. Farmers must know the plants to be planted to get good harvests. Smart Farmer application is made to be a medium of help for young Farmers who do not have sufficient knowledge in conducting farming activities. The Smart Farmer application is created by presenting relevant information such as cultivation techniques, diseases, pests, and benefits related to rice plants. Rice plants were chosen as the subject matter because rice is the primary food choice needed by humans in Indonesia, and at this time farmers have also decreased in number.
\end{abstract}

Keywords : Android, Application, Cultivation, Monitoring, Rice, Learning, Smart Farmers

\section{INTRODUCTION}

The lack of rice farmers, which is currently also a concern by the Ministry of Agriculture of the certain country [1]-[3] Ministry of Agriculture through the Agricultural Human Resource Development and Development Agency in 2017 prepared a Farmer/Human Resources (HR) Regeneration Action Program for Agriculture. For this reason, a study was conducted in making Smart Farmer Applications in Android-based Rice Monitoring and Cultivation in order to assist Farmers Regeneration in gathering information [4]. Android smartphone was chosen as the media application, because it has a form that is minimalist, lightweight, and has high mobility. The Smart Farmer application is created using Android Studio and the Java programming language. In this application, there are two types of valuable content, namely learning and monitoring. In Learning Content there is information such as cultivation techniques, diseases, pests, and benefits related to rice plants [5]. Moreover, on the Monitoring Content, there is information about capital, total production, and income of paddy farmers.

\section{THEORIES}

\subsection{Android}

Android is an operating system for Linux-based mobile devices that includes operating systems, middleware and applications [6]-[8] Android provides an open platform for developers to create their applications. Initially, Google Inc. bought Android Inc., which is a newcomer who makes software for cellphones/smartphones. Then to develop Android, the Open Handset Alliance was formed, a consortium of 34 hardware, software and telecommunications companies, including Google, HTC, Intel, Motorola, Qualcomm, T-Mobile, and Nvidia [9].

\subsection{Learning Media}

The word media is the plural form of the word medium [10]. A medium can be defined as an intermediary or introduction to communication from 
the sender to the recipient. Media is one component of communication, namely as a messenger from communicators to communicants[11]. Based on these definitions, learning media are intermediary tools in the learning process [12]. Learning media is a collection of various types of components that exist in the environment of students so that they are more aroused to take lessons well. Media is something that is used to stimulate the mind, willingness and attention of students to encourage learning activities. Media can also be used as a way to channel material messages to students [13].

\subsection{Unified Modelling Language}

The Unified Modeling Language (UML) is a structure and technique for the object-oriented program (OOP) modeling and design and its application. UML is a methodology for developing an OOP system and a group of tools to support the development of the system [14]. UML was introduced by the Object Management Group, an organization that has developed models, technologies and OOP standards since the 1980s. Now UML has begun to be widely used by OOP practitioners [15]. UML is the basis for object-oriented design tools from IBM. Because it is an application development methodology, UML is the subject of lectures on system development and the discussion will be limited here [16].

\section{METHODOLOGY}

The research material consisted of rice cultivation techniques, rice plant diseases, overcoming rice plants disease, rice pest, overcoming rice pest, and rice crop benefits. This research uses material originating from farmers directly, which is then adapted to existing books, and agricultural websites. The steps taken in this study can be seen in the following step.

- Formulate problems

- Determining goals

- Collect data on system requirements
- Analyze application systems

- Designing application systems

- Test the application system

- Implement the application system

- Distributing questionnaires

- Conclude the results data

The data collection technique from this study was carried out with several of these methods:

1. Observation

2. Questionnaire

3. Interview

4. Library Research

The following are the equations used to obtain rice production.

Prod. $=$ number of clumps $*$ number of tillers

* grain per panicle

* weight per 1000 items

\section{IMPLEMENTATION}

After the overall processes have been carried out, an Android-based smart farmer application design will be created using Android Studio and can be seen in the following picture display.

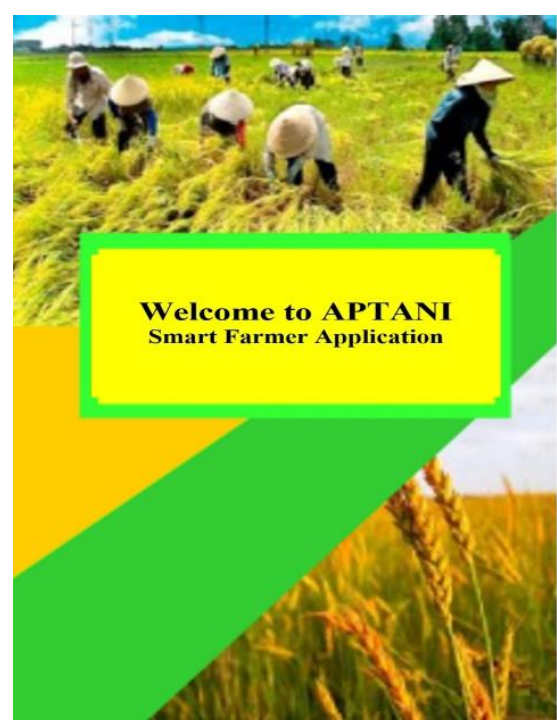

Figure 1. Design of Splash Screen 
The design of the Splash Screen display is a display that will be displayed the first time when the application starts on an android smartphone.

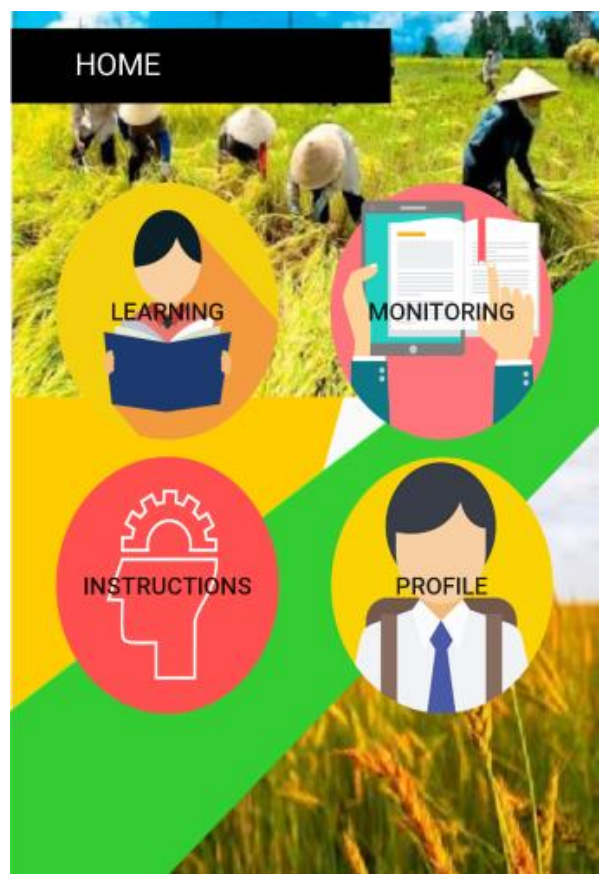

Figure 2. Design of Main Page

The design of the main page is the display that will be displayed after the user has logged in with his account via the login page.

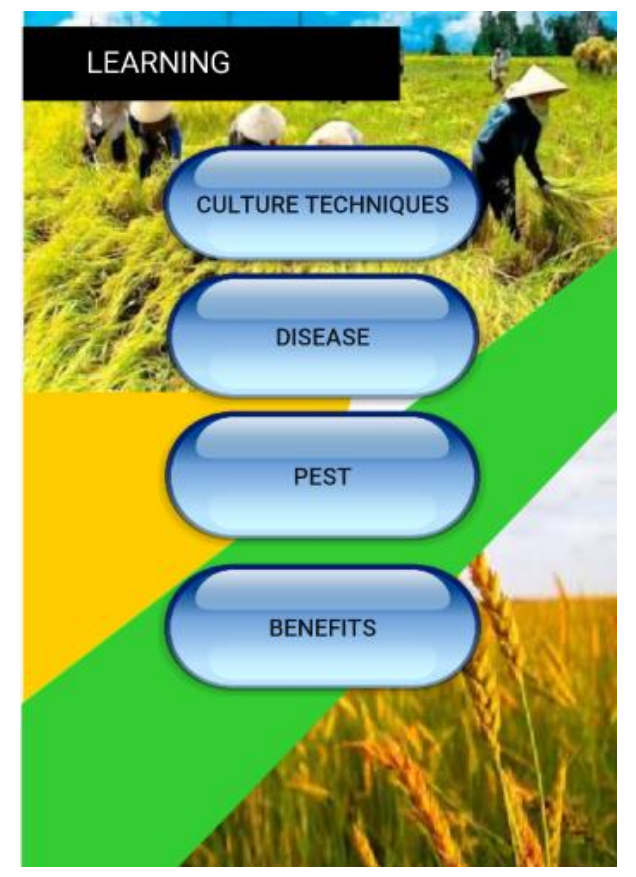

Figure 3. Design of Learning Page
The design of the learning page display is a display that will be displayed after the learning menu on the main page is used.

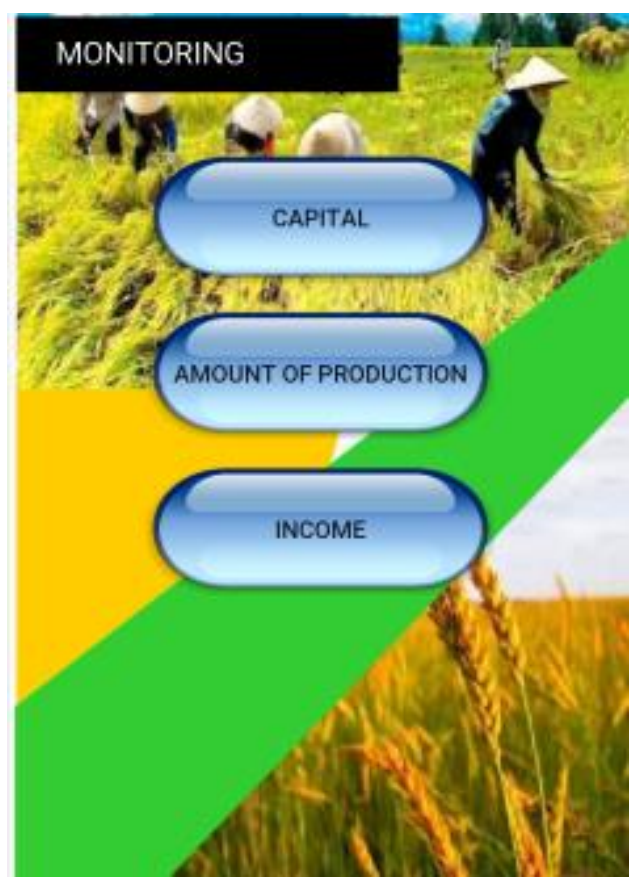

Figure 4. Design of Monitoring Page

The design of the monitoring page is a display that will be displayed after the monitoring menu on the main page is used.

\section{RESULT AND DISCUSSION}

This Farmer Smart application contains information about rice cultivation, and calculates initial capital in conducting rice cultivation, calculates the amount of expenditure, total expenditure, and total selling during production.

There are four factors that support rice production, such as:

- Planting distance

- Number of tillers

- Number of grains per panicle

- Amount of 1000 items per gram 
The following illustration is an example taken of the calculation of rice production [17].

- Determine the spacing of $25 \mathrm{~cm} \mathrm{x} 25 \mathrm{~cm}$, the number of clumps is 160,000 .

- Determine two clumps of rice randomly.

- Calculate the number of tillers.

- Calculate the number of tillers that have panicles.

- Calculate all seeds in the clump and divided by the number of panicles.

Results for first clump

$$
\begin{aligned}
\mathrm{C}_{1} & =\frac{160,000 * 18 * 116 * 30}{1000} \\
& =10,022,400 \operatorname{gram}(\mathrm{s}) \\
& =10,022.4 \mathrm{~kg}(\mathrm{~s}) \\
& =10.022 \operatorname{ton}(\mathrm{s})
\end{aligned}
$$

Results for second clump

$$
\begin{aligned}
\mathrm{C}_{2} & =\frac{160,000 * 14 * 128 * 30}{1000} \\
& =8,601,600 \operatorname{gram}(\mathrm{s}) \\
& =8,601.6 \mathrm{~kg}(\mathrm{~s}) \\
& =8.602 \operatorname{ton}(\mathrm{s})
\end{aligned}
$$

Rice production

$$
\begin{aligned}
\mathrm{P} & =\frac{10.022+8.602}{2} \\
& =9.312 \operatorname{ton}(\mathrm{s}) / \text { ha DGH }
\end{aligned}
$$

\section{CONCLUSION}

From the research that has been done, several conclusions can be taken. The application is made by using Android Studio and the Java programming language so that it helps farmers in carrying out their activities and business. The application can run well on Android smartphones with several versions. Smart Farmer Application in Learning Content has the following information, cultivation techniques, diseases, pests, and benefits related to rice plants. Content Monitoring also has information about the capital, amount of production, and income of rice farmers.

\section{ACKNOWLEDGMENT}

The authors would like to thank for the support and funding provided by the Ministry of Research and Higher Education of the Republic of Indonesia in this study.

\section{REFERENCES}

[1] D. E. Groth and J. A. Bond, "Effects of Cultivars and Fungicides on Rice Sheath Blight, Yield, and Quality," Plant Dis., vol. 91, no. 12, pp. 1647-1650, Dec. 2007.

[2] T. Eddy, B. Alamsyah, S. Aryza, and A. P. U. Siahaan, "An Effect Phenomena Circle Living Field in Secanggang Langkat," Int. J. Civ. Eng. Technol., vol. 9, no. 7, pp. 1575-1580, 2018.

[3] W. M. Rivera, "Human resource development in the agriculture sector: three levels of need," Int. J. Lifelong Educ., vol. 14, no. 1, pp. 65-73, Jan. 1995.

[4] E. Tomé, "Human resource development in the knowledge based and services driven economy," J. Eur. Ind. Train., vol. 35, no. 6, pp. 524-539, Jul. 2011.

[5] J. Wesseler and D. Zilberman, "The economic power of the Golden Rice opposition," Environ. Dev. Econ., vol. 19, no. 06, pp. 724742, Dec. 2014.

[6] A. P. U. Siahaan, "Securing Short Message ServiceUsing Vernam Cipher in Android Operating System," IOSR, Apr. 2016.

[7] R. F. Wijaya, Y. M. Tondang, and A. P. U. Siahaan, "Take Off and Landing Prediction using Fuzzy Logic," Int. J. Recent Trends Eng. Res., vol. 2, no. 12, pp. 127-134, 2016. 
[8] Khairul et al., "Effect of Matrix Size in Affecting Noise Reduction Level of Filtering," Int. J. Eng. Technol., vol. 7, no. 3, pp. 12721275, 2018.

[9] M. Iqbal, M. A. S. Pane, and A. P. U. Siahaan, "SMS Encryption Using One-Time Pad Cipher," IOSR J. Comput. Eng., vol. 18, no. 6, pp. 54-58, 2016.

[10] L. Zhang, "Effectively incorporating instructional media into web-based information literacy," Electron. Libr., vol. 24, no. 3, pp. 294-306, May 2006.

[11] S. Billett, "Accessing and engaging vocational knowledge: instructional media versus everyday practice," Educ. + Train., vol. 38, no. 2, pp. 18-25, Mar. 1996.

[12] J. Goforth, W. F. Metz, and K. Hammer, "Nurturing critical consumers and producers of narrative media," Ref. Serv. Rev., vol. 46, no. 2, pp. 189-204, Jun. 2018.

[13] R. D. Pea, "Learning through multimedia," IEEE Comput. Graph. Appl., vol. 11, no. 4, pp. 58-66, Jul. 1991.

[14] M. Wimmer, "A semi-automatic approach for bridging DSMLs with UML," Int. J. Web Inf. Syst., vol. 5, no. 3, pp. 372-404, Aug. 2009.

[15] B. Achauer, "The DOWL distributed objectoriented language," Commun. ACM, vol. 36, no. 9, pp. 48-55, Sep. 1993.

[16] J. Zhao, W. M. Cheung, and R. I. M. Young, "A consistent manufacturing data model to support virtual enterprises," Int. J. Agil. Manag. Syst., vol. 1, no. 3, pp. 150-158, Dec. 1999.

[17] Waryana Aji, "Cara Menghitung Produksi Tanaman Padi Di Sawah Dengan Metode 4
Faktor - Kabartani,” KabarTani.com, 2016. [Online].

Available : https://kabartani.com/cara menghitung-produksi-tanaman-padi-disawah-dengan-metode-4-faktor.html. [Accessed: 15-Nov-2018]. 